\title{
Isolation and Characterization of Euglena gracilis-Associated Bacteria, Enterobacter sp. CA3 and Emticicia sp. CN5, Capable of Promoting the Growth and Paramylon Production of E. gracilis under Mixotrophic Cultivation
}

\author{
Rubiyatno $^{1} \mathbb{D}$, Kazuhiro Mori ${ }^{2}$, Daisuke Inoue ${ }^{3} \mathbb{D}$, Sunah Kim ${ }^{4} \mathbb{D}$, Jaecheul Yu ${ }^{4} \mathbb{D}$, Taeho Lee ${ }^{4}(\mathbb{D}$, \\ Michihiko Ike $^{3(D)}$ and Tadashi Toyama ${ }^{2, *}$ \\ 1 Integrated Graduate School of Medicine, Engineering, and Agricultural Sciences, University of Yamanashi, \\ 4-3-11 Takeda, Kofu 400-8511, Yamanashi, Japan; g18dtka4@yamanashi.ac.jp \\ 2 Graduate Faculty of Interdisciplinary Research, University of Yamanashi, 4-3-11 Takeda, Kofu 400-8511, \\ Yamanashi, Japan; mori@yamanashi.ac.jp \\ 3 Division of Sustainable Energy and Environmental Engineering, Graduate School of Engineering, \\ Osaka University, 2-1 Yamadaoka, Suita 565-0871, Osaka, Japan; d.inoue@see.eng.osaka-u.ac.jp (D.I.); \\ ike@see.eng.osaka-u.ac.jp (M.I.) \\ 4 Department of Civil and Environmental Engineering, Pusan National University, Busan 46241, Korea; \\ sunah.kim2401@pusan.ac.kr (S.K.); yjcall0715@pusan.ac.kr (J.Y.); leeth55@pusan.ac.kr (T.L.) \\ check for \\ updates \\ * Correspondence: ttohyama@yamanashi.ac.jp; Tel.: +81-55-220-8346
}

Citation: Rubiyatno; Mori, K.; Inoue, D.; Kim, S.; Yu, J.; Lee, T.; Ike, M.;

Toyama, T. Isolation and

Characterization of Euglena gracilis-Associated Bacteria, Enterobacter sp. CA3 and Emticicia sp. CN5, Capable of Promoting the Growth and Paramylon Production of E. gracilis under Mixotrophic Cultivation. Microorganisms 2021, 9 , 1496. https://doi.org/10.3390/ microorganisms 9071496

Academic Editor: Aschwin Engelen

Received: 24 May 2021

Accepted: 8 July 2021

Published: 13 July 2021

Publisher's Note: MDPI stays neutral with regard to jurisdictional claims in published maps and institutional affiliations.

Copyright: (๑) 2021 by the authors. Licensee MDPI, Basel, Switzerland. This article is an open access article distributed under the terms and conditions of the Creative Commons Attribution (CC BY) license (https:// creativecommons.org/licenses/by/ $4.0 /)$.
Abstract: Euglena gracilis produces paramylon, which is a feedstock for high-value functional foods and nutritional supplements. The enhancement of paramylon productivity is a critical challenge. Microalgae growth-promoting bacteria (MGPB) can improve microalgal productivity; however, the MGPB for E. gracilis remain unclear. This study isolated bacteria capable of enhancing E. gracilis growth and paramylon production under mixotrophic conditions. Enterobacter sp. CA3 and Emticicia sp. CN5 were isolated from E. gracilis grown with sewage-effluent bacteria under mixotrophic conditions at $\mathrm{pH} 4.5$ or 7.5 , respectively. In a 7-day E. gracilis mixotrophic culture with glucose, CA3 increased E. gracilis biomass and paramylon production 1.8-fold and 3.5-fold, respectively (at pH 4.5), or 1.9-fold and 3.5-fold, respectively (at pH 7.5). CN5 increased E. gracilis biomass and paramylon production 2.0-fold and 4.1-fold, respectively (at $\mathrm{pH} 7.5$ ). However, the strains did not show such effects on E. gracilis under autotrophic conditions without glucose. The results suggest that CA3 and CN5 promoted both $E$. gracilis growth and paramylon production under mixotrophic conditions with glucose at $\mathrm{pH} 4.5$ and 7.5 (CA3) or $\mathrm{pH} 7.5$ (CN5). This study also provides an isolation method for E. gracilis MGPB that enables the construction of an effective E. gracilis-MGPB-association system for increasing the paramylon yield of E. gracilis.

Keywords: Euglena gracilis; paramylon; associated bacteria; growth promotion; paramylon production promotion; co-culture; Emticicia sp.; Enterobacter sp.

\section{Introduction}

Microalgal biomass is a sustainable and renewable feedstock for value-added products, such as feeds and foods, food supplements, pharmaceuticals, personal care products, and biofuels [1]. Among the microalgal species, Euglena gracilis, a freshwater unicellular flagellated microalga, is among the most promising industrially applicable microalga for producing commercial sources of high-value-added products [2]. E. gracilis can grow photoautotrophically, heterotrophically, and mixotrophically [3-6] and accumulate various metabolites, such as amino acids [6], vitamins [7], polyunsaturated fatty acids [8], and paramylon ( $\beta$-1,3-glucan) [9].

Paramylon has unique and medical functions, such as immunomodulation $[10,11]$, anti-allergy [12], cholesterol-lowering [13], anti-tumor [14], anti-HIV [12], and anti-infection 
activities [15]. Paramylon is thus recognized as a feedstock for high-value functional foods and nutritional supplements. The paramylon industry has received significant attention [2], and its market is expected to increase in the future. E. gracilis can grow and accumulate paramylon under both low and neutral $\mathrm{pH}$ conditions [9]. The cultivation of E. gracilis under acidic conditions gives it an important advantage over other microalgae, as it prevents microbial and bacterial contaminations and enables large-scale cultivation for the paramylon industry. Enhancing the growth and paramylon productivity of E. gracilis is the most important challenge to realizing highly efficient E. gracilis-based industrial paramylon production.

In natural aquatic environments and microalgal cultures, microalgae often co-exist with symbiotic bacteria. Certain symbiotic bacteria [termed microalgae growth-promoting bacteria (MGPB)] can promote microalgal growth in various ways, such as by providing nutrients [16], vitamins [17], phytohormones [18,19], chelators [20], and volatile organic compounds [21]. MGPB associated with several microalgae species have been isolated from microalgal host cultures. For example, a Rhizobium sp. strain was isolated from Chlorella vulgaris [22], a Rhizobium sp. strain was isolated from Botryococcus braunii [23], the Candidatus Phycosocius bacilliformis strain BOTRYCO-2 was isolated from B. braunii [24], Pelagibaca bermudensis KCTC 13073BP and Stappia sp. KCTC 13072BP were isolated from Tetraselmis striata [25], a Pseudomonas sp. was isolated from Scenedesmus sp. LX1 [19,26], and a Marinobacter sp. was isolated from Chlamydomonas reinhardtii [22]. Only one MGPB (Emticicia sp. strain EG3) has been isolated from the cell surface of E. gracilis, and it promoted E. gracilis growth under photoautotrophic conditions [27], although the promotion of E. gracilis paramylon production by EG3 was unclear. Thus, little information is available regarding E. gracilis-associated MGPB and their ability to promote E. gracilis paramylon production.

By contrast, previous studies demonstrated that indole-3-acetic acid (IAA)-producing Vibrio natriegens [28] and extracellular polymeric substance (EPS)-producing Pseudoalteromonas sp. MEBiC 03485 [29] and Pseudoalteromonas sp. MEBiC 03607 [30] improved the growth and paramylon productivity of E. gracilis under heterotrophic conditions. Additionally, strains MEBiC 03485 and MEBiC 03607 increased the expression of genes related to $\beta$-1,3-glucan synthase $[29,30]$. However, these three bacteria were not isolated from E. gracilis-associated environments, but rather they were obtained from microbial culture collection centers. Thus, these bacteria do not have any inherent advantage in associating with E. gracilis cells and building a symbiotic relationship. Screening and isolating MGPB symbiotically associated with $E$. gracilis enable the building of a more effective, sustainable, and practical E. gracilis-bacteria association for increasing paramylon production and contributing to the E. gracilis-based paramylon industry. However, to date, no MGPB that enhance both E. gracilis growth and paramylon production have been isolated from the host E. gracilis.

Therefore, the objectives of this study were to screen, isolate, and characterize MGPB capable of enhancing both E. gracilis growth and paramylon production under mixotrophic conditions. Previous studies reported that E. gracilis showed greater paramylon production and growth during mixotrophic cultivation as compared with photoautotrophic conditions $[3,5,6]$; therefore, we conducted experiments under mixotrophic conditions with a 12-h light and 12-h dark cycle. Because we recently observed that indigenous bacterial communities in sewage effluent promotes E. gracilis growth [31], we attempted to isolate MGPB from E. gracilis grown in sewage effluent. First, E. gracilis was cultured with a sewage-effluent bacterial community under mixotrophic conditions at an acidic $\mathrm{pH}(4.5)$ or a neutral $\mathrm{pH}$ (7.5), after which E. gracilis-associated bacteria were isolated as MGPB candidates. Second, MGPB showing growth- and paramylon-production-promoting effects on E. gracilis were screened and characterized. Finally, MGPB showing growth- and paramylon-production-promoting effects on E. gracilis were examined in E. gracilis-MGPB co-culture experiments. 


\section{Materials and Methods}

\subsection{Microalgae and Culture Conditions}

Axenic (bacteria-free) E. gracilis (NIES-48) was obtained from the Microbial Culture Collection at the National Institute for Environmental Studies (NIES Collection; Tsukuba, Japan) and cultured in C medium supplemented with $400 \mathrm{mg} \mathrm{L}^{-1}$ yeast extract and $600 \mathrm{mg} \mathrm{L}^{-1}$ polypeptone (referred to here as CYP medium), as recommended by NIES Collection. Each liter of $\mathrm{C}$ medium contained $150 \mathrm{mg} \mathrm{Ca}\left(\mathrm{NO}_{3}\right)_{2} \cdot 4 \mathrm{H}_{2} \mathrm{O}, 100 \mathrm{mg} \mathrm{KNO}$, $50 \mathrm{mg} \beta-\mathrm{Na}_{2}$ glycerophosphate $5 \mathrm{H}_{2} \mathrm{O}, 40 \mathrm{mg} \mathrm{MgSO}_{4} \cdot 7 \mathrm{H}_{2} \mathrm{O}, 500 \mathrm{mg}$ Tris (hydroxymethyl) aminomethane, $0.1 \mu \mathrm{g}$ vitamin B12, $0.1 \mu \mathrm{g}$ biotin, $10 \mu \mathrm{g}$ thiamine $\mathrm{HCl}$, and $3 \mathrm{~mL}$ PIV metals $\left(1000 \mathrm{mg} \mathrm{L}^{-1} \mathrm{Na}_{2}\right.$ EDTA $\cdot \mathrm{H}_{2} \mathrm{O}, 196 \mathrm{mg} \mathrm{L}^{-1} \mathrm{FeCl}_{3} \cdot 6 \mathrm{H}_{2} \mathrm{O}, 36 \mathrm{mg} \mathrm{L}^{-1} \mathrm{MnCl}_{2} \cdot 4 \mathrm{H}_{2} \mathrm{O}$, $10.4 \mathrm{mg} \mathrm{L}^{-1} \mathrm{ZnCl}_{2}, 4 \mathrm{mg} \mathrm{L}^{-1} \mathrm{CoCl}_{2} \cdot 6 \mathrm{H}_{2} \mathrm{O}$, and $\left.2.5 \mathrm{mg} \mathrm{L}{ }^{-1} \mathrm{Na}_{2} \mathrm{MoO}_{4} \cdot \mathrm{H}_{2} \mathrm{O}\right)$. The $\mathrm{pH}$ of the CYP medium was adjusted to 7.5. E. gracilis cells were sub-cultured by transferring them to fresh CYP medium every 1 or 2 weeks in a growth chamber maintained at $28 \pm 1{ }^{\circ} \mathrm{C}$ with fluorescent lamps at a photosynthetic photon-flux density of $80 \mu \mathrm{mol} \mathrm{m}^{-2} \mathrm{~s}^{-1}$ and a 12-h photoperiod. Because $E$. gracilis use ammonium as a nitrogen source, for each experiment, axenic $E$. gracilis cells were pre-cultured in $\mathrm{C}-\mathrm{NH}_{4}$ medium comprising $\mathrm{C}$ medium with $100 \mathrm{mg} \mathrm{L}^{-1}\left(\mathrm{NH}_{4}\right)_{2} \mathrm{SO}_{4}$ at a $\mathrm{pH} 4.5$ or 7.5 , depending on the experiment. Pre-cultured axenic $E$. gracilis cells were incubated in the growth chamber for 1 week.

\subsection{Sewage Effluent Sample and Collection of Indigenous Bacterial Communities from the Effluent}

Sewage effluent was collected from the final sedimentation tank of a conventionally activated sludge process of a sewage-treatment plant in Kofu City, Yamanashi, Japan. The water quality of the effluent was $11.8 \mathrm{mg} \mathrm{L}^{-1}$ of total organic carbon, $6.5 \mathrm{mg} \mathrm{L}^{-1}$ $\mathrm{NH}_{4}-\mathrm{N}, 0.08 \mathrm{mg} \mathrm{L}^{-1} \mathrm{NO}_{2}-\mathrm{N}, 4.2 \mathrm{mg} \mathrm{L}^{-1} \mathrm{NO}_{3}-\mathrm{N}$, and $3.2 \mathrm{mg} \mathrm{L}^{-1} \mathrm{PO}_{4}-\mathrm{P}$. The effluent sample was first passed through a glass microfiber filter (pore size, $1.6 \mu \mathrm{m}$; GF/A grade; GE Healthcare UK, Ltd., Little Chalfont, UK) to remove suspended solids and organisms larger than bacteria (including microalgae) from the effluent sample. Therefore, the effluent filtrate included an indigenous bacterial community. To collect the indigenous bacteria, the effluent sample $(300 \mathrm{~mL})$ was filtered through a sterilized membrane filter (pore size, $0.2 \mu \mathrm{m}$; polytetrafluoroethylene; Merck Millipore Ltd., Cork, Ireland), which were then placed into $30 \mathrm{~mL}$ of $\mathrm{C}$ medium in a 50-mL tube, vortexed at maximum speed for $1 \mathrm{~min}$, shaken at 150 rotations/min (rpm) for $60 \mathrm{~min}$, and vortexed at maximum speed for 1 min to detach the bacterial cells from the filter and suspend them in $C$ medium. The number of culturable bacteria in the bacterial suspension was quantified using R2A agar plates $\left(0.5 \mathrm{~g} \mathrm{~L}^{-1}\right.$ peptone, $0.5 \mathrm{~g} \mathrm{~L}^{-1}$ yeast extract, $0.5 \mathrm{~g} \mathrm{~L}^{-1}$ casamino acid, $0.5 \mathrm{~g} \mathrm{~L}^{-1}$ glucose, $0.5 \mathrm{~g} \mathrm{~L}^{-1}$ soluble starch, $0.3 \mathrm{~g} \mathrm{~L}^{-1} \mathrm{~K}_{2} \mathrm{HPO}_{4}, 0.05 \mathrm{~g} \mathrm{~L}^{-1} \mathrm{MgSO}_{4} \cdot 7 \mathrm{H}_{2} \mathrm{O}$, and $0.3 \mathrm{~g} \mathrm{~L}^{-1}$ sodium pyruvate $(\mathrm{pH} 7.0)$, and agar $\left.15 \mathrm{~g} \mathrm{~L}^{-1}\right)$. The culturable bacterial density was $5.7 \times 10^{5} \mathrm{CFU} \mathrm{mL}^{-1}$.

\subsection{Culturing E. gracilis with a Bacterial Community Derived from Sewage Effluent and Isolating Bacteria Associated with E. gracilis}

Corn steep liquor (CSL; Oji Cornstarch Co., Ltd., Tokyo, Japan) was used as an organic carbon source for the mixotrophic cultures. Ten milliliters of $E$. gracilis (pre-cultured in C-NH ${ }_{4}$ medium with $0.5 \mathrm{~g} \mathrm{~L}^{-1} \mathrm{CSL}$ at $\mathrm{pH} 4.5$ or 7.5) was added to $100 \mathrm{~mL}$ of $\mathrm{C}-\mathrm{NH}_{4}$ medium with $0.5 \mathrm{~g} \mathrm{~L}^{-1} \mathrm{CSL}$ at $\mathrm{pH} 4.5$ or 7.5 in a 200-mL glass flask, into which $10 \mathrm{~mL}$ of the sewage-effluent bacterial suspension was inoculated. The E. gracilis sewage-effluent bacterial cultures in $\mathrm{C}-\mathrm{NH}_{4}$ with $\mathrm{CSL}$ at $\mathrm{pH} 4.5$ or 7.5 were incubated in a growth chamber with shaking at $150 \mathrm{rpm}$ for $10 \mathrm{~d}$. Additionally, E. gracilis cultures in $\mathrm{C}-\mathrm{NH}_{4}$ medium with $0.5 \mathrm{~g} \mathrm{~L}^{-1}$ CSL at $\mathrm{pH} 4.5$ or 7.5 but without sewage-effluent bacteria were prepared and incubated as bacteria-free control cultures. The experiments were conducted in triplicate. After $10 \mathrm{~d}$ of culture, $25 \mathrm{~mL}$ of the E. gracilis-effluent bacterial culture was transferred into a 50-mL tube and vortexed at maximum speed for $3 \mathrm{~min}$ to disperse the E. gracilis and bacterial cells. The sample was then filtered through a GF/A glass microfiber filter to remove E. gracilis cells. The filtrate containing bacteria was serially diluted and spread on 
R2A agar plates with a $\mathrm{pH}$ of 4.5 or 7.5 , which were incubated at $28^{\circ} \mathrm{C}$ for 2 weeks. In this study, bacteria obtained from cultures at $\mathrm{pH} 4.5$ were defined as acidophilic bacteria, and those obtained from cultures at pH 7.5 were defined as neutrophilic bacteria. Eight acidophilic bacteria and 15 neutrophilic bacteria were isolated, and a pure culture of each strain was maintained on $\mathrm{R} 2 \mathrm{~A}$ agar at $\mathrm{pH} 4.5$ or 7.5 . Because CSL reportedly increases the biomass and paramylon productivity of E. gracilis [9], CSL was initially used as an organic carbon source for the mixotrophic cultures of E. gracilis; however, CSL is a mixture of organic compounds. For detailed examination, we used pure glucose as the organic carbon source for E. gracilis mixotrophic culture in subsequent experiments.

\subsection{Screening of MGPB Capable of Enhancing Both E. gracilis Growth and Paramylon Production}

Each isolated bacterial strain was cultured in R2A liquid medium ( $\mathrm{pH} 4.5$ or 7.5) at $28^{\circ} \mathrm{C}$ and with shaking (150 rpm) until the late logarithmic growth phase. The cells were harvested by centrifugation $\left(10,000 \times g, 24^{\circ} \mathrm{C}\right.$, and $\left.5 \mathrm{~min}\right)$ and washed twice with C- $\mathrm{NH}_{4}$ medium ( $\mathrm{pH} 4.5$ or 7.5). Each acidophilic or neutrophilic bacterial cell culture was inoculated into $E$. gracilis $\mathrm{C}-\mathrm{NH}_{4}$ medium at $\mathrm{pH} 4.5$ or 7.5 with $5 \mathrm{~g} \mathrm{~L}^{-1}$ glucose at an optical density at $600 \mathrm{~nm}\left(\mathrm{OD}_{600}\right)$ of 0.05 . The co-cultures of E. gracilis with each isolated bacterial strain were incubated in a growth chamber with shaking at $150 \mathrm{rpm}$ for $7 \mathrm{~d}$. The initial biomass of $E$. gracilis was approximately $40 \mathrm{mg}$ dry weight $\mathrm{L}^{-1}$. On day 7 , concentrations of E. gracilis chlorophyll $a+b$, biomass, and paramylon were measured. Control cultures including E. gracilis cells alone (without bacterial inoculation) in $\mathrm{C}-\mathrm{NH}_{4}$ medium ( $\mathrm{pH} 4.5$ or 7.5) were also prepared and analyzed similarly for comparison. The E. gracilis growthand paramylon-production-promoting abilities of the isolated bacteria were assessed by comparing the biomass and paramylon concentrations at the end of 7-d culturing with bacterial inoculation relative to control cultures.

\subsection{Identification and Characterization of the CA3 and CN5 Strains}

Among the isolated bacterial strains, strains CA3 (acidophilic bacterium) and CN5 (neutrophilic bacterium) showed the highest growth- and paramylon-production-promoting abilities at pH 4.5 and 7.5, respectively. Strains CA3 and CN5 were characterized and identified using physiological and phylogenetic analyses. Physiological characterization was performed using an API 20NE Kit (BioMérieux Japan, Tokyo, Japan) according to the manufacturer's instructions. Comparative $16 \mathrm{~S}$ rRNA gene-sequence analysis was performed, as follows: almost full-length $16 \mathrm{~S}$ rRNA genes were amplified by PCR using the primers $8 \mathrm{~F}\left(5^{\prime}-\right.$ AGAGTTTGATCCTGGCTCAG-3') and 1510R (5'-GGTTACCTTGTTACGACTT-3'). Genuslevel identifications were carried out based on 16S rRNA gene-sequence similarities with those of type-strain sequences in NCBI GenBank using BLAST. The 16S rRNA sequence data [1431 base pairs (bp)] of CA3 and CN5 were submitted to the DDBJ/EMBL/GenBank databases under accession numbers LC604062 and LC604063, respectively.

Bacterial IAA production was evaluated as described previously [32], with some modifications. The bacterial colony was inoculated in $100 \mathrm{~mL}$ of C-NH $\mathrm{NH}_{4}$ medium with $5 \mathrm{~g} \mathrm{~L}^{-1}$ glucose ( $\mathrm{pH} 4.5$ or 7.5$)$ with or without $0.05 \%(w / v)$ L-tryptophan and incubated at $28{ }^{\circ} \mathrm{C}$ and $150 \mathrm{rpm}$ for $1 \mathrm{~d}$. The culture was collected and centrifuged $\left(10,000 \times g, 4{ }^{\circ} \mathrm{C}\right.$, and $10 \mathrm{~min}$ ), and $500 \mu \mathrm{L}$ supernatant was mixed with $750 \mu \mathrm{L}$ Salkowski reagent (98 $\mathrm{mL} \mathrm{35 \%}$ $\mathrm{HClO}_{4}$ plus $2 \mathrm{~mL}$ of $0.5 \mathrm{M} \mathrm{FeCl}_{3}$ ) and incubated at $24^{\circ} \mathrm{C}$ for $30 \mathrm{~min}$. The development of a pink color indicated IAA production, and the absorbance at $535 \mathrm{~nm}\left(\mathrm{~A}_{535}\right)$ was measured. The IAA concentration was calculated using pure IAA as a standard (Kanto Chemical Co., Inc., Tokyo, Japan).

Bacterial EPS production was evaluated as described previously [29], with specific

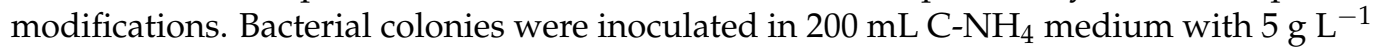
glucose ( $\mathrm{pH} 4.5$ or 7.5) and incubated at $28^{\circ} \mathrm{C}$ and $150 \mathrm{rpm}$ for $1 \mathrm{~d}$. Each culture was collected and centrifuged $\left(10,000 \times g, 4{ }^{\circ} \mathrm{C}\right.$, and $\left.20 \mathrm{~min}\right)$, and the supernatant was gently mixed with three volumes of ice-cold $100 \%$ ethanol and incubated overnight at $4{ }^{\circ} \mathrm{C}$. The precipitated EPS was collected by centrifugation $\left(10,000 \times g, 4{ }^{\circ} \mathrm{C}\right.$, and $\left.20 \mathrm{~min}\right)$ and dried. 
This EPS was defined as free EPS. Bacterial cells were collected from the above 1-d culture by centrifugation $\left(10,000 \times g, 24{ }^{\circ} \mathrm{C}\right.$, and $\left.20 \mathrm{~min}\right)$ and mixed with $0.9 \% \mathrm{NaCl}$ solution, with this mixture homogenized and shaken using a vortex for $3 \mathrm{~min}$ and centrifuged $(10,000 \times g$, $4{ }^{\circ} \mathrm{C}$, and $\left.20 \mathrm{~min}\right)$. The supernatant was gently mixed with three volumes of ice-cold $100 \%$ ethanol and incubated at $4{ }^{\circ} \mathrm{C}$ overnight. The precipitated EPS was collected by centrifugation $\left(10,000 \times g, 4^{\circ} \mathrm{C}\right.$, and $\left.20 \mathrm{~min}\right)$, dried, and defined as cell-bound EPS. Free and cell-bound EPS were dissolved in hot distilled water, and the total sugar content of the EPS was determined in each sample by the phenol-sulfuric acid method [33]. The total protein content of the EPS was estimated in each sample using a BCA protein assay kit (Takara Bio, Shiga, Japan). Total sugar and protein contents in the EPS were calculated as $\mathrm{mg} \mathrm{L}^{-1}$ of culture medium.

\subsection{Growth of CA3 and CN5 Utilizing Glucose}

Strain CA3 was pre-cultured at $28^{\circ} \mathrm{C}$ in liquid R2A medium ( $\left.\mathrm{pH} 4.5\right)$ with shaking (150 rpm) until it reached the late logarithmic growth phase. Similarly, strain CN5 was pre-cultured at $28^{\circ} \mathrm{C}$ in R2A medium ( $\left.\mathrm{pH} 7.5\right)$ with shaking (150 rpm) un2w1til it reached the late logarithmic growth phase. The cells of each strain were harvested by centrifugation $\left(10,000 \times g, 24{ }^{\circ} \mathrm{C}\right.$, and $\left.5 \mathrm{~min}\right)$ and washed twice with $\mathrm{C}-\mathrm{NH}_{4}$ medium $(\mathrm{pH} 4.5$ or 7.5$)$. The

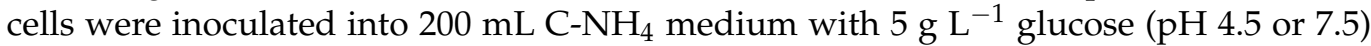
in a 500-mL flask until reaching an $\mathrm{OD}_{600}$ of 0.05 , after which they were incubated for $5 \mathrm{~d}$ at $28^{\circ} \mathrm{C}$ and $150 \mathrm{rpm}$ in the dark. The bacterial cell densities $\left(\mathrm{OD}_{600}\right)$ and glucose concentrations were monitored during the incubation period. The growth experiments were conducted in triplicate.

\subsection{Co-Culturing E. gracilis with CA3 or CN5 under Acidic and Neutral pH with or without Glucose}

Ten milliliters of E. gracilis pre-cultured in C-NH 4 medium with $5 \mathrm{~g} \mathrm{~L}^{-1}$ glucose (pH

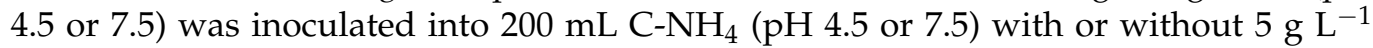
glucose. The initial biomass of $E$. gracilis was approximately $40 \mathrm{mg}$ dry weight $\mathrm{L}^{-1}$. CA3 or CN5 cells were pre-cultured in liquid R2A medium at $28^{\circ} \mathrm{C}$ with shaking $(150 \mathrm{rpm})$ at $\mathrm{pH} 4.5$ or 7.5 , respectively, until they reached late logarithmic growth phase. CA3 or CN5 cells were harvested by centrifugation $\left(10,000 \times g, 24{ }^{\circ} \mathrm{C}\right.$, and $\left.5 \mathrm{~min}\right)$ and washed twice with $\mathrm{C}-\mathrm{NH}_{4}$ medium (pH 4.5 or 7.5). $\mathrm{CN} 3$ or $\mathrm{CN} 5$ cells were inoculated at an $\mathrm{OD}_{600}$ of 0.05 into $E$. gracilis $\mathrm{C}-\mathrm{NH}_{4}$ medium at $\mathrm{pH} 4.5$ or 7.5 with or without $5 \mathrm{~g} \mathrm{~L}^{-1}$ glucose. Control cultures including E. gracilis cells alone (without bacterial inoculation), CA3 or CN5 cells alone (without E. gracilis), and C-NH 4 medium with $5 \mathrm{~g} \mathrm{~L}^{-1}$ glucose alone (without E. gracilis and bacterial cultures) were also prepared. All culture flasks were incubated in a growth chamber with shaking at $150 \mathrm{rpm}$ for $7 \mathrm{~d}$. During the experiments, chlorophyll $a+b$, E. gracilis biomass, paramylon, and glucose concentrations were monitored on the initial day and days 3 and 7. The experiments were conducted in triplicate. The growth- and paramylon-production-promoting effects of CA3 and CN5 were evaluated for comparison with E. gracilis axenic control culture in 7-d cultures.

\subsection{Scanning Electron Microscopy (SEM) of E. gracilis Cell Surfaces}

For SEM experiments, E. gracilis cells were collected from the co-culture experiment at $7 \mathrm{~d}$ and centrifuged at $3000 \times g$ for $5 \mathrm{~min}$ at $24{ }^{\circ} \mathrm{C}$. Additionally, the collected E. gracilis cells were washed using the same biomass (dry weight)-measurement method: vortex mixing for $60 \mathrm{~s}$, centrifugation $\left(3000 \times g, 24{ }^{\circ} \mathrm{C}\right.$, and $\left.5 \mathrm{~min}\right)$, and washing with distilled water. The E. gracilis cells (with or without the above washing process) were then fixed with $4 \%$ osmium tetroxide solution at $4{ }^{\circ} \mathrm{C}$ for $3 \mathrm{~h}$, dehydrated at room temperature $\left(\sim 24^{\circ} \mathrm{C}\right)$ in solutions containing progressivelyincreasing ethanol concentrations (30-100\%; $15 \mathrm{~min}$ /incubation), and finally dried at the carbon dioxide critical point. The dried samples were coated using an osmium plasma coater (OPC80T; Filgen, Nagoya, Japan) and then examined by SEM using a JEOL SEM instrument (JSM 6320F; JEOL Ltd., Tokyo, Japan). 


\subsection{Analytical Procedures}

The chlorophyll concentrations in the E. gracilis cultures were measured spectrophotometrically after extraction with $100 \%$ methanol for $30 \mathrm{~min}$ [34]. The $\mathrm{A}_{665}$ and $\mathrm{A}_{650}$ of each extract were measured using a UVmini-1240 spectrophotometer (Shimadzu Co. Ltd., Kyoto, Japan). Total chlorophyll (Chl; $\mathrm{Chl} a+b)$ concentration $\left(\mu \mathrm{g} \mathrm{mL}{ }^{-1}\right)$ was calculated, as follows:

$$
\text { Chl } a+b\left(\mu \mathrm{g} \mathrm{mL}^{-1}\right)=\left(4 \times \mathrm{A}_{665}\right)+\left(25.5 \times \mathrm{A}_{650}\right)
$$

The biomass (dry weight) of E. gracilis samples was measured, as follows: $25 \mathrm{~mL}$ of each culture was collected into a 50-mL centrifuge tube and vortexed for $60 \mathrm{~s}$ to uniformly suspend bacterial and microalgal cells. Each mixture was centrifuged $\left(3000 \times g, 24{ }^{\circ} \mathrm{C}\right.$, and $5 \mathrm{~min}$ ), the pellet was washed with $25 \mathrm{~mL}$ distilled water, and the centrifugation and wash steps were repeated one time. Subsequently, each E. gracilis pellet was suspended in $25 \mathrm{~mL}$ distilled water, collected on a pre-weighed GF / A glass fiber filter, dried at $90^{\circ} \mathrm{C}$ for $3 \mathrm{~h}$, and then weighed. We confirmed by SEM observations that the collected E. gracilis cells contained no CA3 or CN5 cells.

Paramylon was extracted from E. gracilis cells using the sodium dodecyl sulfateethylenediaminetetraacetic acid (SDS-EDTA) method. Each E. gracilis culture $(25 \mathrm{~mL})$ was collected into a 50-mL centrifuge tube, ultrasonicated for $1 \mathrm{~min}$, vortexed for $30 \mathrm{~s}$, and then centrifuged $\left(3000 \times g, 24^{\circ} \mathrm{C}\right.$, and $\left.5 \mathrm{~min}\right)$ to remove the supernatant. The collected E. gracilis pellets were washed thrice by centrifugation $\left(3000 \times g, 24{ }^{\circ} \mathrm{C}\right.$, and $\left.5 \mathrm{~min}\right)$, resuspended in $25 \mathrm{~mL}$ distilled water, and incubated with $10 \mathrm{~mL}$ of ethanol for $30 \mathrm{~min}$ at room temperature $\left(24{ }^{\circ} \mathrm{C}\right)$ before another round of centrifugation $\left(8000 \times g, 24^{\circ} \mathrm{C}\right.$, and $\left.5 \mathrm{~min}\right)$. The collected E. gracilis cells were mixed with $10 \mathrm{~mL}$ SDS-EDTA reagent (1\% SDS: $\% \mathrm{Na}_{2}$.EDTA), incubated in a water bath at $90^{\circ} \mathrm{C}$ for $30 \mathrm{~min}$, and centrifuged $\left(8000 \times g, 24^{\circ} \mathrm{C}\right.$, and $5 \mathrm{~min}$ ), after which the supernatant was removed. Each collected $E$. gracilis pellet was mixed with $1 \mathrm{~mL}$ SDS-EDTA reagent and $9 \mathrm{~mL}$ distilled water, vortexed, and centrifuged $(8000 \times g$, $24{ }^{\circ} \mathrm{C}$, and $5 \mathrm{~min}$ ), after which each supernatant was removed from the tube. The collected E. gracilis pellets were then mixed with $20 \mathrm{~mL}$ distilled water, vortexed, and centrifuged $\left(8000 \times g, 24{ }^{\circ} \mathrm{C}\right.$, and $\left.5 \mathrm{~min}\right)$, after which each supernatant was removed from the tube. Each collected E. gracilis pellet was then mixed with $5 \mathrm{~mL} 1 \mathrm{~mol} \mathrm{~L}^{-1} \mathrm{NaOH}$, vortexed, and incubated at room temperature $\left(24^{\circ} \mathrm{C}\right)$ for $12 \mathrm{~h}$. A $0.5-\mathrm{mL}$ aliquot from each tube was transferred to a test tube with $0.5 \mathrm{~mL}$ of $5 \%$ phenol solution and $2.5 \mathrm{~mL}$ sulfuric acid. The test tubes were gently mixed and incubated at room temperature $\left(24{ }^{\circ} \mathrm{C}\right)$ for 30 min, after which the $\mathrm{A}_{480}$ of each solution was measured using a spectrophotometer. A standard calibration curve was prepared using commercially available $100 \%$ paramylon ( $\beta$-1,3-glucan from E. gracilis; Sigma-Aldrich, St. Louis, MO, USA).

The glucose concentration in each culture was measured using a Shimadzu highperformance liquid chromatography system (Shimadzu Co. Ltd.) with a refractive index detector and a Shodex SUGAR SH1011 column ( $300 \mathrm{~mm} \times 8.0 \mathrm{~mm}$; Showa Denko K. K., Tokyo, Japan). The mobile phase was $1 \mathrm{mmol} \mathrm{L}^{-1}$ sulfuric acid solution, and the column was maintained at $50{ }^{\circ} \mathrm{C}$.

\subsection{Statistical Analysis}

Each value presented represents the results of three replicates $(n=3)$ per experiment. All results are expressed as the mean \pm standard deviation (SD). Statistical significance $(p<0.05)$ was analyzed using the paired-samples $t$-test with SPSS Statistics (v.22.0; IBM Corp., Armonk, NY, USA).

\section{Results}

3.1. Isolation and Identification of Bacteria Promoting the Growth and Paramylon Production of E. gracilis

E. gracilis cells were cultured in C-NH $\mathrm{N}_{4}$ with $0.5 \mathrm{~g} \mathrm{~L}^{-1} \mathrm{CSL}$ under mixotrophic conditions at $\mathrm{pH} 4.5$ or 7.5 with or without sewage-effluent bacteria. E. gracilis clearly showed faster growth at both $\mathrm{pH}$ values when co-cultured with sewage-effluent bacteria than with- 
out (Figure S1). Therefore, this suggested that MGPB for E. gracilis must have been present among the sewage-effluent bacteria and supported E. gracilis growth under mixotrophic conditions at $\mathrm{pH} 4.5$ or 7.5 .

After E. gracilis cells were co-cultured with sewage-effluent bacteria at $\mathrm{pH} 4.5$ or 7.5 , eight acidophilic bacterial strains and 15 neutrophilic bacterial strains were isolated, respectively (Table S1). All isolates showed at least $95 \%$ sequence identity with known type strains, as determined by BLAST searches for the partial 16S rDNA sequences of the isolated strains (Table S1). Among the isolated acidophilic bacteria strains, three (CA1, CA2, and CA7) were Microbacterium sp., three (CA6, CA8, and CA9) were Achromobacter sp., one (CA4) was a Kaistia sp., and one (CA3) was an Enterobacter sp. Among the isolated neutrophilic bacterial strains, three (CN1, CN10, and CN11) were Pedobacter sp., one (CN2) was a Phenylobacterium sp., one (CN3) was a Sphingomonas sp., one (CN4) was an Achromobacter sp., one (CN5) was an Emticicia sp., one (CN6) was an Elizabethkingia sp., one (CN7) was an Enterobacter sp., one (CN8) was a Herminiimonas sp., three (CN9, CH13, and CN15) were Sediminibacterium sp., one (CN12) was an Erythrobacter sp., and one (CN14) was a Polaromonas sp. Among these strains, CA3 (an acidophilic bacteria) and CN5 (a neutrophilic bacteria) showed the highest growth- and paramylon-production-promoting effects on E. gracilis under mixotrophic conditions with $0.5 \mathrm{~g} \mathrm{~L}^{-1}$ glucose at a $\mathrm{pH}$ of 4.5 or 7.5 , respectively (data not shown).

On R2A agar, the CA3 colonies appeared convex, circular, smooth, lustrous, and white in color and were Gram-negative and rod-shaped $(0.8-1.0 \times 1.2-1.8 \mu \mathrm{m})$ (Figure S2). CA3 tested positive for nitrate reduction, glucose fermentation, aesculin hydrolysis, and $\beta$ galactosidase activity but negative for oxidase, arginine dihydrolase, urease, and gelatinase activities. CA3 utilized D-glucose, L-arabinose, D-mannose, D-mannitol, glucosamine, D-maltose, gluconate, malate, citrate, and phenylacetate but did not utilize caprate or adipate. Almost the entire $16 \mathrm{~S}$ rRNA gene sequence (1467 bp) of CA3 was similar to that of Enterobacter roggenkampii DSM 16,690 ${ }^{\mathrm{T}}$ [99.6\% (1461/1467 bp) sequence similarity], Enterobacter mori LMG $25706^{\mathrm{T}}$ [99.5\% (1460/1467 bp)], Enterobacter oligotrophicus CCA6 ${ }^{\mathrm{T}}$ [99.5\% (1460/1467 bp)], Enterobacter wuhouensis WCHEs120002 ${ }^{\mathrm{T}}$ [98.8\% (1450/1467 bp)], Enterobacter asburiae ATCC $35953^{\mathrm{T}}$ [98.8\% (1450/1467 bp)], and Enterobacter xiangfangensis LMG27195 ${ }^{\mathrm{T}}$ [98.8\% (1449/1467 bp)]. Based on phylogenetic analysis, CA3 was identified as an Enterobacter sp.

By contrast, colonies of strain CN5 on R2A agar were convex, circular, smooth, lustrous, and orange in color. Similar to the CA3 strain, the CN5 strain was also Gram-negative and rod-shaped $(0.7-0.9 \times 1.2-1.6 \mu \mathrm{m})$ (Figure S2). CA5 cells were positive for oxidase, aesculin hydrolysis, and $\beta$-galactosidase activities but negative for nitrate reduction, glucose fermentation, and arginine dihydrolase, urease, and gelatinase activities. Strain CN5 utilized D-glucose, D-mannose, glucosamine, and D-maltose but did not utilize L-arabinose, D-mannitol, gluconate, caprate, adipate, malate, citrate, or phenylacetate as the sole carbon source. Almost the entire 16S rRNA gene sequence (1431 bp) of CN5 was similar to the sequences of Emticicia fontis IMCC1731 ${ }^{\mathrm{T}}$ [97.9\% (1403/1433 bp)], Emticicia ginsengisoli Gsoil $085^{\mathrm{T}}$ (97.6\% [1399/1434 bp]), Emticicia soli ZZ-4 ${ }^{\mathrm{T}}$ [97.5\% (1396/1432 bp)], Emticicia oligotrophica GPTSA100-15 ${ }^{\mathrm{T}}$ [94.4\% (1354/1435 bp)], Emticicia paludis HMF3850 ${ }^{\mathrm{T}}$ [94.1\% (1349/1433 bp)], and Emticicia aquatica HMF2925 ${ }^{\mathrm{T}}$ [93.9\% (1346/1434 bp)]. Based on phylogenetic analysis, CN5 was identified as an Emticicia sp.

Previous reports show that IAA- and EPS-producing bacteria promote E. gracilis growth and paramylon production [28,29]. Therefore, we tested the IAA- and EPSproducing activities of CA3 and CN5. CA3 and CN5 did not produce IAA in C-NH $4+$ glucose medium in the absence of L-tryptophan, which is the main precursor for the IAAbiosynthesis pathways in bacteria (Table 1). Additionally, CA3 produced EPS in C$\mathrm{NH}_{4}+$ glucose medium at both $\mathrm{pH} 4.5$ and 7.5, whereas CN5 produced EPS in C-NH 4 + glucose medium only at pH 7.5 (Table 1 ). 
Table 1. Indole-3-acetic acid (IAA)-producing and extracellular polymeric substance (EPS)-producing activities of Enterobacter sp. CA3 and Emticicia sp. CN5 strains isolated in this study.

\begin{tabular}{|c|c|c|c|c|c|c|}
\hline \multirow{3}{*}{$\begin{array}{l}\text { Strain and pH } \\
\text { Condition }\end{array}$} & \multicolumn{2}{|c|}{ IAA-Producing Activity } & \multicolumn{4}{|c|}{ EPS-Producing Activity } \\
\hline & \multirow{2}{*}{$\begin{array}{l}\text { IAA Concentration with } \\
\text { L-Tryptophan } \\
\left(\mu \mathrm{mol} \mathrm{L}^{-1}\right)^{1}\end{array}$} & \multirow{2}{*}{$\begin{array}{l}\text { IAA Concentration } \\
\text { without } \\
\text { L-Tryptophan }\end{array}$} & \multicolumn{2}{|c|}{ Free EPS } & \multicolumn{2}{|c|}{ Cell-Bound EPS } \\
\hline & & & $\begin{array}{c}\text { Sugar } \\
\left(\mathrm{mg} \mathrm{L}^{-1}\right)^{1}\end{array}$ & $\begin{array}{c}\text { Protein } \\
\left(\mathrm{mg} \mathrm{L}^{-1}\right)^{1}\end{array}$ & $\begin{array}{c}\text { Sugar } \\
\left(\mathrm{mg} \mathrm{L}^{-1}\right)^{1}\end{array}$ & $\begin{array}{c}\text { Protein } \\
\left(\mathrm{mg} \mathrm{L}^{-1}\right)^{1}\end{array}$ \\
\hline $\begin{array}{c}\text { CA3 } \\
\text { at } \mathrm{pH} 4.5\end{array}$ & $5.48 \pm 0.24$ & Negative & $26.7 \pm 0.03$ & $16.5 \pm 0.85$ & $1.22 \pm 0.00$ & $1.07 \pm 0.21$ \\
\hline $\begin{array}{c}\mathrm{CA3} \\
\text { at } \mathrm{pH} 7.5\end{array}$ & $8.11 \pm 0.23$ & Negative & $35.1 \pm 0.08$ & $17.1 \pm 0.11$ & $2.01 \pm 0.00$ & $2.49 \pm 0.24$ \\
\hline $\begin{array}{c}\mathrm{CN} 5 \\
\text { at } \mathrm{pH} 4.5\end{array}$ & $\mathrm{NT}^{2}$ & $\mathrm{NT}^{2}$ & $\mathrm{NT}^{2}$ & $\mathrm{NT}^{2}$ & $\mathrm{NT}^{2}$ & $\mathrm{NT}^{2}$ \\
\hline $\begin{array}{c}\text { CN5 } \\
\text { at } \mathrm{pH} 7.5\end{array}$ & $2.51 \pm 0.07$ & Negative & $31.7 \pm 0.02$ & $17.1 \pm 0.06$ & $2.14 \pm 0.00$ & $2.54 \pm 0.32$ \\
\hline
\end{tabular}

${ }^{1}$ All values are presented as the mean $\pm \mathrm{SD}(n=3) ;{ }^{2} \mathrm{NT}$ indicates a condition that was not tested because CN5 could not be grown at $\mathrm{pH} 4.5$.

\subsection{Growth of CA3 and CN5 Utilizing Glucose as a Sole Carbon Source}

$\mathrm{CA} 3$ or $\mathrm{CN} 5$ were cultured in $\mathrm{C}-\mathrm{NH}_{4}$ medium with $5 \mathrm{~g} \mathrm{~L}^{-1}$ glucose at $\mathrm{pH} 4.5$ or 7.5. CA3 rapidly utilized $5 \mathrm{~g} \mathrm{~L}^{-1}$ glucose at both $\mathrm{pH} 4.5$ and 7.5, and the bacterial cell density $\left(\mathrm{OD}_{600}\right)$ increased in parallel with glucose uptake, reaching a stationary growth phase within $12 \mathrm{~h}$ (Figure 1A). CN5 rapidly utilized $5 \mathrm{~g} \mathrm{~L}^{-1}$ glucose at $\mathrm{pH} 7.5$, and bacterial growth paralleled glucose uptake, reaching stationary phase within $12 \mathrm{~h}$ (Figure 1B). However, $\mathrm{CN} 5$ did not utilize glucose or grow at $\mathrm{pH} 4.5$.
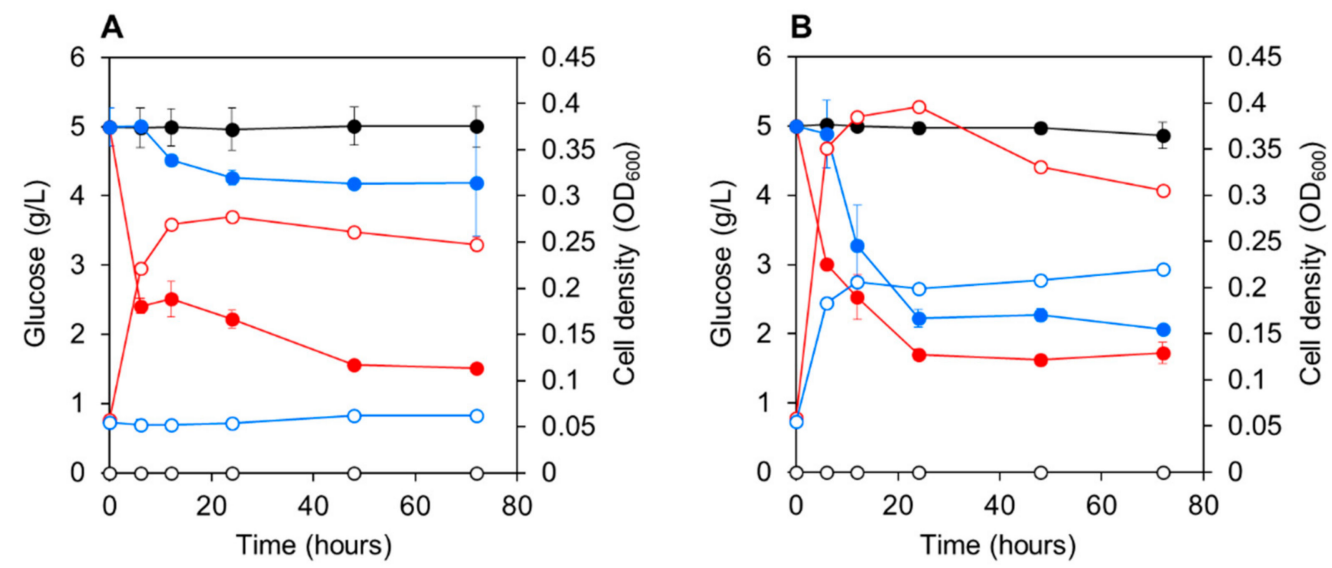

Figure 1. Glucose consumption and growth of Enterobacter sp. CA3 and Emticicia sp. CN5 cells at pH 4.5 (A) and 7.5 (B). Closed circles: glucose concentrations in CA3 cultures (red), CN5 cultures (blue), and bacteria-free control cultures (black). Open circles: cell densities ( $\left.\mathrm{OD}_{600}\right)$ of CA3 cultures (red), CN5 cultures (blue), and bacteria-free control cultures (black). Data shown represent means \pm SD $(n=3)$.

\subsection{Co-Culturing E. gracilis with Strain CA3 or CN5 under Photoautotrophic or Mixotrophic Conditions at $\mathrm{pH} 4.5$ or 7.5}

E. gracilis cells were co-cultured with $\mathrm{CA} 3$ or $\mathrm{CN} 5$ cells in $\mathrm{C}-\mathrm{NH}_{4}$ medium without glucose (photoautotrophic condition) or with $5 \mathrm{~g} \mathrm{~L}^{-1}$ glucose (mixotrophic condition) at $\mathrm{pH} 4.5$ or 7.5 for $7 \mathrm{~d}$. At $\mathrm{pH} 4.5$ under photoautotrophic conditions without glucose, the chlorophyll, biomass, and paramylon concentrations of E. gracilis co-cultured with CA3 or $\mathrm{CN} 5$ and axenic control E. gracilis cultures increased at comparable rates, although slight differences were observed (Figure 2A-C). 

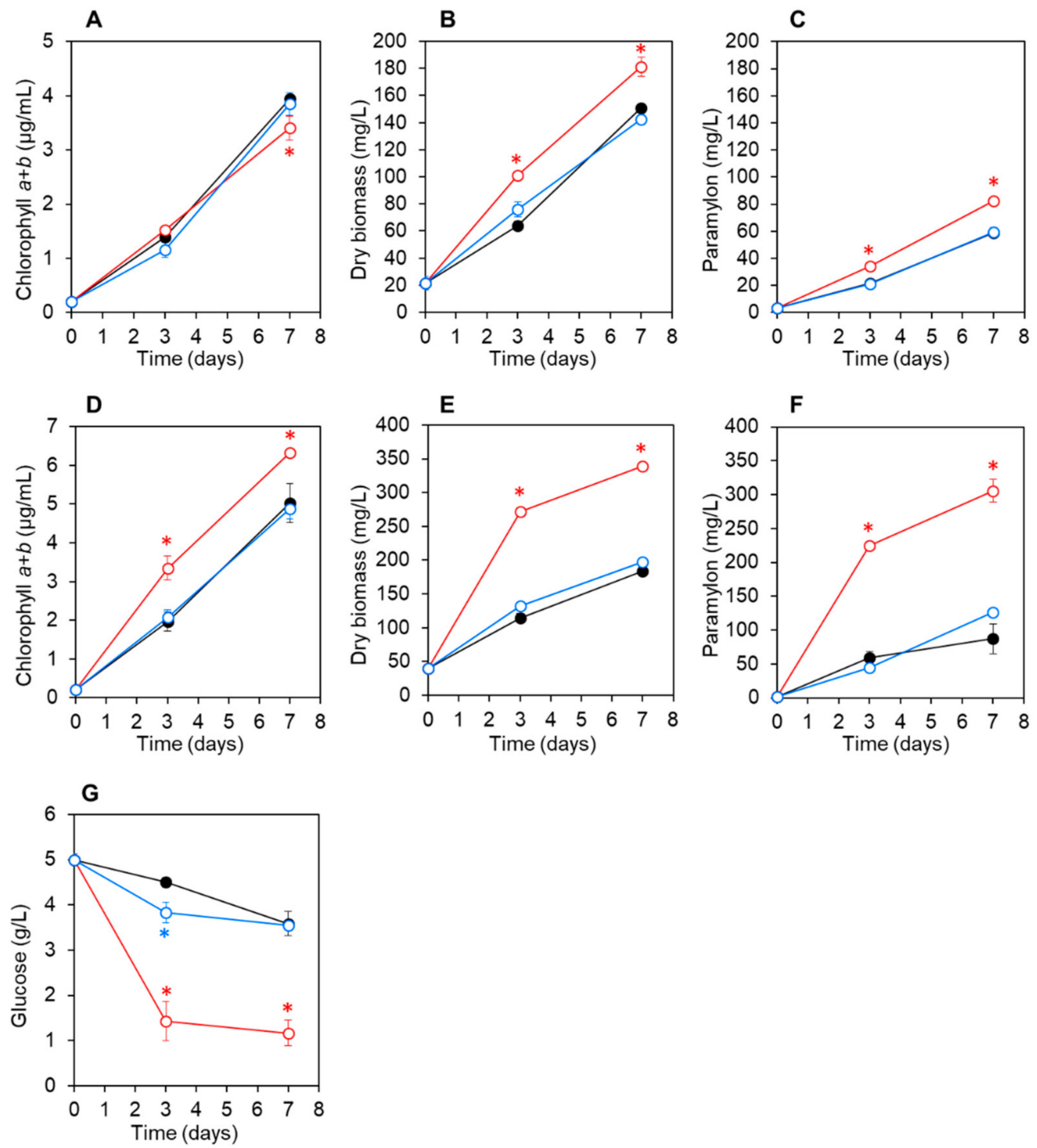

Figure 2. Changes in chlorophyll, paramylon, and glucose concentrations and biomass of Euglena gracilis cultured at $\mathrm{pH} 4.5$ under autotrophic conditions without glucose $(\mathbf{A}-\mathbf{C})$ and under mixotrophic conditions with $5 \mathrm{~g} \mathrm{~L}^{-1}$ glucose $(\mathbf{D}-\mathbf{G})$. Open red circles: E. gracilis co-cultured with Enterobacter sp. CA3; open blue circles: E. gracilis co-cultured with Emticicia sp. CN5; and closed black circles: E. gracilis axenic control cultures. Data shown represent means $\pm \operatorname{SD}(n=3)$. Asterisks indicate significant difference $(p<0.05)$ between the E. gracilis co-culture with CA3 or CN5 and the E. gracilis axenic control culture.

E. gracilis biomass and paramylon concentrations were slightly but significantly higher $(p<0.05)$ after $3 \mathrm{~d}$ in E. gracilis co-cultured with CA3 than when co-cultured with CN5 or in axenic control cultures (Figure 2B,C). At $\mathrm{pH} 4.5$ under mixotrophic conditions with glucose, the chlorophyll, biomass, and paramylon concentrations of $E$. gracilis increased rapidly and were significantly higher $(p<0.05)$ in E. gracilis co-cultured with strain CA3 than when co-cultured with CN5 or in axenic control cultures (Figure 2D-F). Moreover, glucose concentration decreased more rapidly in E. gracilis co-cultured with CA3 than with CN5 or in axenic control E. gracilis cultures (Figure $2 \mathrm{G}$ ). After $7 \mathrm{~d}$, the final biomass and paramylon concentrations of E. gracilis co-cultured with CA3 were 1.8- and 3.5-fold higher, respectively, as compared with those of control E. gracilis cultured under mixotrophic conditions with glucose (Table 2). 
Table 2. Biomass and paramylon productivities of Euglena gracilis cells co-cultured with Enterobacter sp. CA3 or Emticicia sp. CN5 and axenic control cultures under various conditions.

\begin{tabular}{|c|c|c|c|c|}
\hline \multicolumn{2}{|c|}{ Culture Condition } & \multirow{2}{*}{ Co-Culture Condition } & \multicolumn{2}{|c|}{$\begin{array}{l}\text { Final Biomass and Paramylon } \\
\text { Concentration after } 7 \mathrm{~d}\end{array}$} \\
\hline cart & concition & & $\begin{array}{c}\text { Biomass } \\
\left(\mathrm{mg} \mathrm{L}^{-1}\right)^{1}\end{array}$ & $\begin{array}{l}\text { Paramylon } \\
\left(\mathrm{mg} \mathrm{L}^{-1}\right)^{1}\end{array}$ \\
\hline \multirow{6}{*}{$\mathrm{pH} 4.5$} & \multirow{3}{*}{ Autotrophic } & Co-culture with CA3 & $\begin{array}{l}181.3 \pm 7.1 \\
(1.2 \text {-fold })^{2}\end{array}$ & $\begin{array}{l}82.5 \pm 3.5 \\
(1.4 \text {-fold })\end{array}$ \\
\hline & & Co-culture with CN5 & $\begin{array}{c}142.7 \pm 1.3 \\
(0.95 \text {-fold })\end{array}$ & $\begin{array}{l}59.4 \pm 2.8 \\
(1.0 \text {-fold })\end{array}$ \\
\hline & & Control & $150.7 \pm 0.7$ & $58.9 \pm 2.3$ \\
\hline & \multirow{3}{*}{$\begin{array}{l}\text { Mixotrophic } \\
\text { with glucose }\end{array}$} & Co-culture with CA3 & $\begin{array}{c}338.7 \pm 4.2 \\
(1.8 \text {-fold })\end{array}$ & $\begin{array}{c}305.7 \pm 16.8 \\
(3.5 \text {-fold })\end{array}$ \\
\hline & & Co-culture with CN5 & $\begin{array}{c}197.3 \pm 4.8 \\
(1.1 \text {-fold })\end{array}$ & $\begin{array}{c}126.3 \pm 1.3 \\
(1.4-\text { fold })\end{array}$ \\
\hline & & Control & $184.0 \pm 5.3$ & $187.1 \pm 22.4$ \\
\hline \multirow{6}{*}{ pH 7.5} & \multirow{3}{*}{ Autotrophic } & Co-culture with CA3 & $\begin{array}{c}169.3 \pm 0.2 \\
(1.3 \text {-fold })\end{array}$ & $\begin{array}{l}50.6 \pm 1.1 \\
(1.3 \text {-fold })\end{array}$ \\
\hline & & Co-culture with CN5 & $\begin{array}{c}141.3 \pm 2.3 \\
(1.1 \text {-fold })\end{array}$ & $\begin{array}{l}37.9 \pm 5.0 \\
(1.0 \text {-fold })\end{array}$ \\
\hline & & Control & $133.3 \pm 4.2$ & $37.9 \pm 6.5$ \\
\hline & \multirow{3}{*}{$\begin{array}{l}\text { Mixotrophic } \\
\text { with glucose }\end{array}$} & Co-culture with CA3 & $\begin{array}{c}508.0 \pm 1.1 \\
(1.9 \text {-fold })\end{array}$ & $\begin{array}{c}443.6 \pm 17.7 \\
(3.5 \text {-fold })\end{array}$ \\
\hline & & Co-culture with CN5 & $\begin{array}{c}540.0 \pm 2.8 \\
(2.0-\text { fold })\end{array}$ & $\begin{array}{c}518.9 \pm 41.7 \\
(4.1-\text {-fold })\end{array}$ \\
\hline & & Control & $266.7 \pm 3.1$ & $128.0 \pm 2.0$ \\
\hline
\end{tabular}

${ }^{1}$ All values are presented as the mean $\pm \mathrm{SD}(n=3) ;{ }^{2}$ The number in parentheses indicates the ratio of each value as compared with each control experimental value (co-culture with CA3/control or co-culture with CN5/control).

At pH 7.5 under photoautotrophic conditions without glucose, the chlorophyll, biomass, and paramylon concentrations of E. gracilis co-cultured with CA3 or CN5 and axenic control $E$. gracilis cultures increased at comparable rates, although slight differences were noted (Figure $3 \mathrm{~A}-\mathrm{C}$ ). At $\mathrm{pH} 7.5$ under mixotrophic conditions with glucose, the chlorophyll concentrations in E. gracilis co-cultured with $\mathrm{CA} 3$ or $\mathrm{CN} 5$ and control cultures increased at comparable rates (Figure 3D).

E. gracilis biomass and paramylon concentrations increased rapidly and were significantly higher $(p<0.05)$ in E. gracilis co-cultured with strain CA3 or CN5 than those in axenic control cultures (Figure 3E,F). Additionally, the glucose concentration in E. gracilis co-cultured with CA3 or CN5 decreased more rapidly than in the control E. gracilis culture (Figure $3 \mathrm{G}$ ). After $7 \mathrm{~d}$, the final biomass and paramylon concentrations of E. gracilis cocultured with CA3 were 1.9- and 3.5-fold higher, respectively, as compared with the control E. gracilis culture. Moreover, after $7 \mathrm{~d}$, the final biomass and paramylon concentrations of E. gracilis co-cultured with CN5 were 2.0- and 4.1-fold higher, respectively, as compared with the control E. gracilis culture under mixotrophic conditions (Table 2). In control cultures containing CA3 or CN5 alone ( $\mathrm{pH} 4.5$ or 7.5), E. gracilis biomass (collected on GF/A filters) and paramylon (extracted using the SDS-EDTA method) were not detected. 

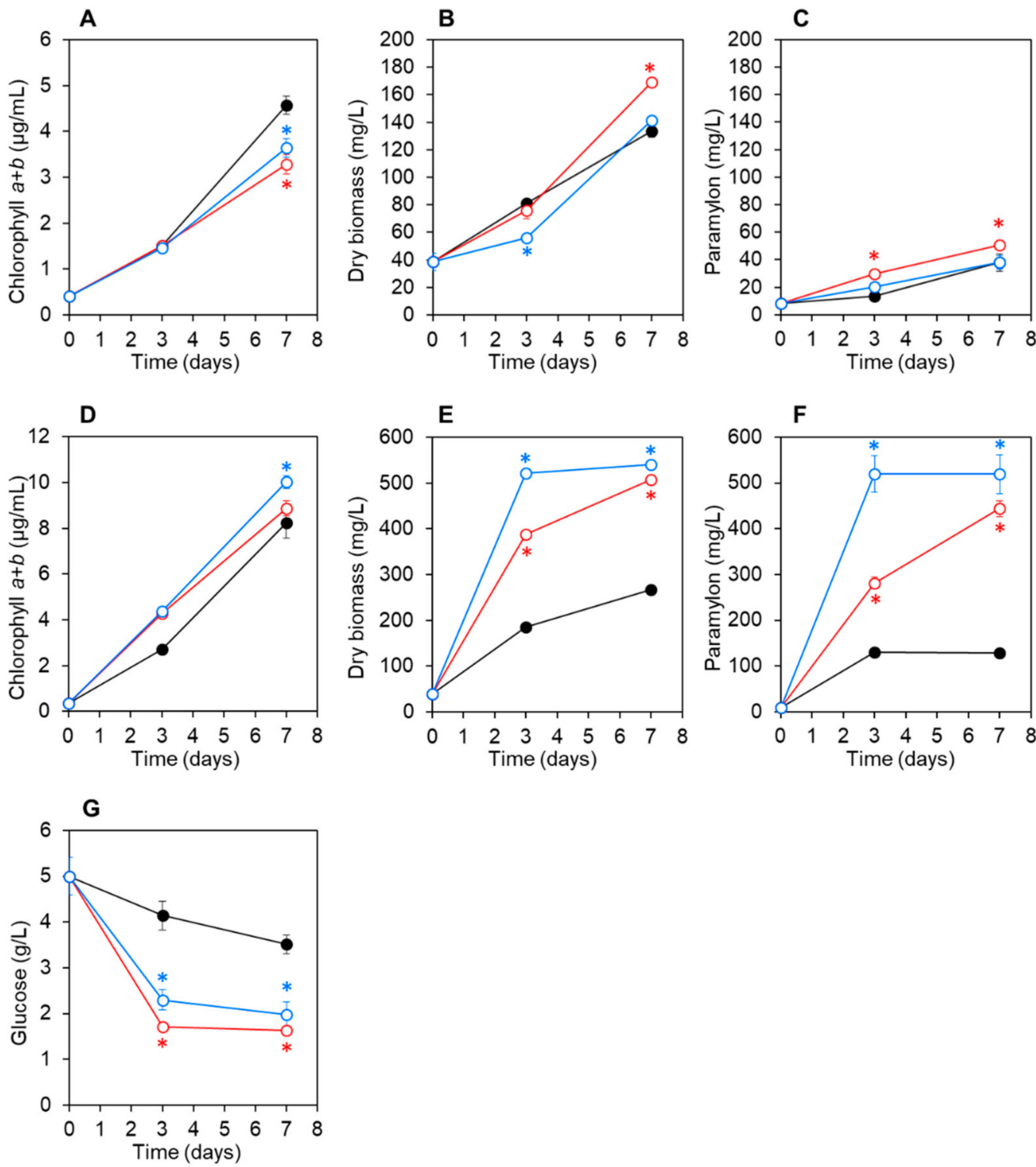

Figure 3. Changes in chlorophyll, paramylon, and glucose concentrations and biomass of Euglena gracilis cultured at $\mathrm{pH} 7.5$ under autotrophic conditions without glucose $(\mathrm{A}-\mathrm{C})$ and under mixotrophic conditions with $5 \mathrm{~g} \mathrm{~L}^{-1}$ glucose (D-G). Open red circles: E. gracilis co-cultured with Enterobacter sp. CA3; open blue circles: E. gracilis co-cultured with Emticicia sp. CN5; and the closed black circles: E. gracilis axenic control cultures. Data shown represent means $\pm \operatorname{SD}(n=3)$. Asterisks indicate significant difference $(p<0.05)$ between the E. gracilis co-culture with CA3 or CN5 and the E. gracilis axenic control culture.

SEM observations revealed that CA3 and CN5 attached to E. gracilis cells in co-cultures under mixotrophic conditions at $\mathrm{pH} 4.5$ or 7.5 , respectively. Interestingly, CA3 and CN5 attached to the flagella of E. gracilis rather than the main cell surface (Figure 4A,B,D,E), although the reasons for this remain unclear. Moreover, the EPS matrix was observed at interfaces between the E. gracilis surface and CA3 or CN5 (Figure 4B,E). However, after the washing process, almost all CA3 and CN5 cells had detached from the E. gracilis surfaces (Figure 4C,F). 


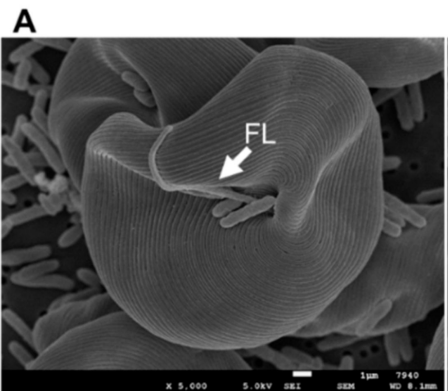

B

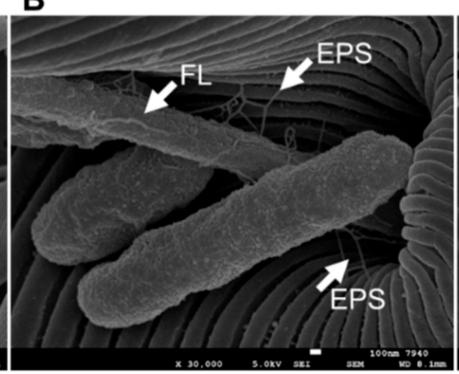

C

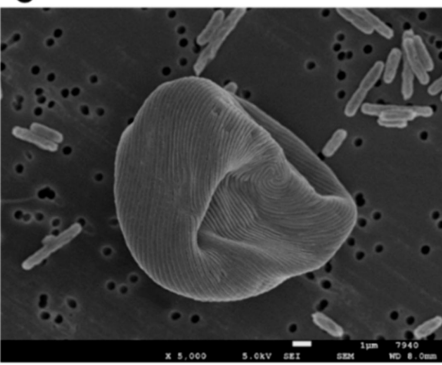

$\mathbf{F}$

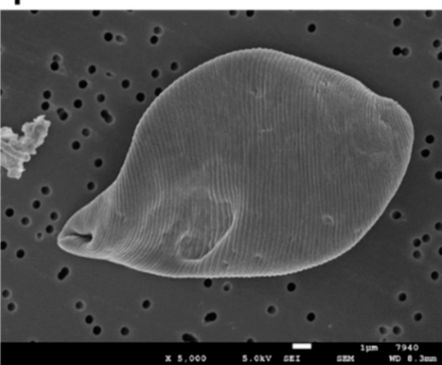

Figure 4. Scanning electron microscopy images of Euglena gracilis cells after $7 \mathrm{~d}$ of co-culture with Enterobacter sp. CA3 without washing $(\mathbf{A}, \mathbf{B})$ or after washing $(\mathbf{C})$ or after $7 \mathrm{~d}$ of co-culture with Emticicia sp. CN5 without washing (D,E) or after washing (F). The FL arrows in panels $(\mathbf{A}, \mathbf{B}, \mathbf{D}, \mathbf{E})$ point to the flagella of $E$. gracilis. The EPS arrows in panels $(\mathbf{B}, \mathbf{E})$ point to extracellular polymeric substance matrix. The white scale bars in panels $(\mathbf{A}, \mathbf{C}, \mathbf{D}, \mathbf{F})$ represent $1 \mu \mathrm{m}$, and the scale bars in panels (B,E) represent $100 \mathrm{~nm}$.

\section{Discussion}

In this study, Enterobacter sp. CA3 and Emticicia sp. CN5 were isolated from the surfaces of $E$. gracilis cells grown with sewage-effluent bacteria under mixotrophic conditions at $\mathrm{pH} 4.5$ or 7.5 , respectively. Both bacterial strains were capable of significantly promoting the growth and paramylon production of E. gracilis at their respective $\mathrm{pH}$ values during a 7-d cultivation (Figures 2 and 3). Additionally, we observed that CA3 and CN5 attached to the flagella of $E$. gracilis cells and presumably formed a symbiotic association with E. gracilis (Figure 4A,B,D,E). Enterobacter sp. CA3 and Emticicia sp. CN5 represent the first isolated E. gracilis-associated bacteria capable of promoting E. gracilis growth and paramylon production under mixotrophic conditions.

Various Enterobacter spp. have been isolated from soil and water, a variety of plant species, natural animal commensals, and the human gut microbiota [35]. In the present study, Enterobacter sp. CA3 was successfully isolated from E. gracilis surfaces after growth with sewage-effluent bacteria at $\mathrm{pH} 4.5$ as an MGPB. This strain is the first MGPB identified that belongs to the Enterobacter genus. Some Enterobacter spp. are acidophilic $[36,37]$ and can grow over a wide range of $\mathrm{pH}$ conditions ( $\mathrm{pH}$ 2-9) [38]. Although CA3 was isolated from E. gracilis grown at $\mathrm{pH} 4.5$, it exhibited viability across a wide range of $\mathrm{pH}$ values and showed growth- and paramylon-promoting activities at both $\mathrm{pH} 4.5$ and 7.5 (Figures 1-3). Several Emticicia spp. bacteria have also been isolated from various aquatic and soil environments [39-41]. Emticicia sp. EG3 was recently isolated from E. gracilis grown in sewage effluent and shown to promote its growth under autotrophic and neutral $\mathrm{pH}$ conditions [27]. Emticicia sp. CN5, isolated in the present study, represents the second reported E. gracilis-associated MGPB, and the first Emticicia sp. capable of promoting paramylon production.

Enterobacter sp. CA3 utilized glucose for its growth (Figure 1) and significantly enhanced both the biomass and paramylon production of E. gracilis under mixotrophic conditions with glucose at both $\mathrm{pH} 4.5$ and 7.5 but showed little or no enhancement under autotrophic conditions without glucose (Figures 2 and 3). By contrast, Emticicia sp. CN5 
utilized glucose for its growth at $\mathrm{pH} 7.5$ and enhanced both E. gracilis biomass and paramylon production under mixotrophic conditions with glucose at $\mathrm{pH} 7.5$ but did not show such enhancement under autotrophic conditions without glucose (Figures 2 and 3). Interestingly, the growth- and paramylon-production-promoting effects on E. gracilis of the two strains were dependent on the mixotrophic condition with glucose and a viable $\mathrm{pH}$ condition.

$V$. natriegens produces IAA in E. gracilis medium with L-tryptophan and promotes the growth and paramylon production of E. gracilis [28]. We found that CA3 and CN5 produced IAA in C-NH $\mathrm{NH}_{4}+$ glucose medium with L-tryptophan but not when cultured in $\mathrm{C}-\mathrm{NH}_{4}+$ glucose medium without L-tryptophan (Table 1). Moreover, CA3 and CN5 promoted the growth and paramylon production of E. gracilis in $\mathrm{C}-\mathrm{NH}_{4}+$ glucose without L-tryptophan (Figures 2 and 3). Thus, the growth-promoting factors of CA3 and CN5 must differ from that of IAA. By contrast, the EPS-producing Pseudoalteromonas sp. MEBiC 03485 promotes the growth and paramylon production of E. gracilis, and supplementation with its free EPS at $133 \mathrm{mg} \mathrm{L}^{-1}$ or $333 \mathrm{mg} \mathrm{L}^{-1}$ significantly promoted the biomass and paramylon production of E. gracilis [29]. In the present study, CA3 produced free EPS in

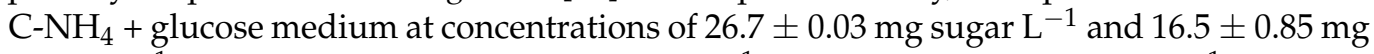
protein $\mathrm{L}^{-1}$ at $\mathrm{pH} 4.5$ and $35.1 \pm 0.08 \mathrm{mg}$ sugar $\mathrm{L}^{-1}$ and $17.1 \pm 0.11 \mathrm{mg}^{-1}$ protein $\mathrm{L}^{-1}$ at $\mathrm{pH}$ 7.5. Similarly, CN5 also produced free EPS in C- $\mathrm{NH}_{4}+$ glucose medium at concentrations of $31.7 \pm 0.02 \mathrm{mg}_{\text {sugar }} \mathrm{L}^{-1}$ and $17.1 \pm 0.06 \mathrm{mg}$ protein $\mathrm{L}^{-1}$ at $\mathrm{pH} 7.5$ (Table 1). Furthermore, CA3 and CN5 produced EPS and attached to the surface of E. gracilis cells via the EPS matrix (Figure 4). Thus, EPS produced by CA3 and CN5 can potentially promote the growth and paramylon production of $E$. gracilis. However, the detected concentration of EPS produced by CA3 and CN5 was much lower than the previously reported effective EPS concentrations (133 and $333 \mathrm{mg} \mathrm{L}^{-1}$ ), suggesting the possibility that CA3 and CN5 might produce major factors other than EPS that are responsible for promoting growth and paramylon production.

These results clearly indicate that the growth- and paramylon-production-promoting factors of CA3 and CN5 are related to glucose metabolism or cell growth (Figures 2 and 3). For example, the promoting factors might be produced through glucose metabolism or glucose-dependent growth to a high cell density and thereby promote $E$. gracilis cell growth and paramylon production. By contrast, CA3 and CN5 did not promote chlorophyll synthesis (Figures 2 and 3). Chlorophylls are essential and limiting factors for photosynthesis [42] and also important in mixotrophic cultivation of E. gracilis [3]. Thus, the promoting factors of $\mathrm{CA} 3$ and $\mathrm{CN} 5$ might act more strongly in a heterotrophic mode than in an autotrophic mode under mixotrophic cultivation, which consists of autotrophic and heterotrophic growth modes. However, we did not test the effect of the bacteria under E. gracilis heterotrophic culture conditions.

In this study, we did not identify the factors or mechanisms by which CA3 and CN5 promote E. gracilis growth and paramylon production under mixotrophic conditions with glucose. MGPB can promote microalgal growth in various ways. Additionally, Zhu and Wakisaka [43] showed that the addition of ferulic acid made from rice promotes the growth and paramylon production of E. gracilis. Exogenous phytohormones, cytokinins, and abscisic acid can also promote the growth of E. gracilis [44]. Thus, it is apparent that various factors have the potential to promote the growth and paramylon production of E. gracilis, and further studies are needed to clarify the mechanisms whereby CA3 and CN5 promote these activities in E. gracilis.

After co-culturing E. gracilis cells with CA3 for $7 \mathrm{~d}$ under mixotrophic conditions with glucose, the biomass and paramylon productivity of $E$. gracilis increased by 1.8and 3.5-fold, respectively, at $\mathrm{pH} 4.5$ and by 1.9- and 3.5-fold, respectively, at $\mathrm{pH} 7.5$ and relative to sterile E. gracilis cultures (Table 2). Additionally, the biomass and paramylon productivity of E. gracilis increased by 2.0 - and 4.1 -fold, respectively, at $\mathrm{pH} 7.5$ when cocultured with CN5 as compared with sterile E. gracilis culture (Table 2). Although the cultivation conditions differed, the promoting effects of CA3 and CN5 were higher than those (a $17-23 \%$ increase in biomass and a $25-35 \%$ increase in paramylon production) 
reported previously for $V$. natriegens [28], EPS-producing Pseudoalteromonas sp. MEBiC 03485 [29], and Pseudoalteromonas sp. MEBiC 03607 [30]. Therefore, CA3 and CN5 represent promising and useful MGPBs for increasing both biomass and paramylon yields of E. gracilis under mixotrophic conditions. Furthermore, the ability to cultivate E. gracilis under acidic conditions with CA3 provides an important advantage in terms of preventing microalgal and bacterial contamination, enabling large-scale cultivation of E. gracilis. Moreover, the attachment of CA3 and CN5 to the surface of E. gracilis flagella suggests that they might form a durable symbiotic association with E. gracilis. However, for the biotechnological application of CA3 and CN5, the method of co-culturing E. gracilis with these strains needs to be optimized in further studies. These findings demonstrated that our screening and isolation methods enabled the construction of an effective and practical E. gracilis-MGPBassociation system for increasing the paramylon yield of E. gracilis.

Supplementary Materials: The following are available online at https:/ / www.mdpi.com/article/10 .3390 / microorganisms9071496/s1. Figure S1: Images of Euglena gracilis cultures in C-NH4 medium, Figure S2: Images of Enterobacter sp. CA3 and Emticicia sp. CN5 colonies on R2A agar and their Gram staining, Table S1: List of bacterial strains isolated in this study.

Author Contributions: R. and T.T. designed the study and performed all experiments; R. contributed to the experiments, data analysis, and preparation of the manuscript; K.M., D.I., S.K., J.Y., T.L. and M.I. contributed to the developing of research ideas and revision of the manuscript; T.T. contributed to the preparation and revision of the manuscript. All authors have read and agreed to the published version of the manuscript.

Funding: This study was supported in part by a Bilateral Joint Research Project (grant number: JPJSBP120208808) from the Japan Society for the Promotion of Science and a Grant-in-Aid for Challenging Exploratory Research (grant number: 19K04663) from the Ministry of Education, Culture, Sports, Science, and Technology of Japan.

Data Availability Statement: The $16 \mathrm{~S}$ rRNA sequence data (1431 bp) of CA3 and CN5 were submitted to the DDBJ/EMBL/GenBank databases under accession numbers LC604062 and LC604063, respectively.

Conflicts of Interest: There are no conflicts of interest to declare.

\section{References}

1. Barsanti, L.; Gualtieri, P. Is exploitation of microalgae economically and energetically sustainable? Algal. Res. 2018, 31, 107-115. [CrossRef]

2. Gissibl, A.; Sun, A.; Care, A.; Nevalainen, H.; Sunna, A. Bioproducts from Euglena gracilis: Synthesis and applications. Front. Bioeng. Biotechnol. 2019, 7, 108. [CrossRef]

3. Yamane, Y.I.; Utsunomiya, T.; Watanabe, M.; Sasaki, K. Biomass production in mixotrophic culture of Euglena gracilis under acidic condition and its growth energetics. Biotechnol. Lett. 2001, 23, 1223-1228. [CrossRef]

4. Ogbonna, J.C.; Ichige, E.; Tanaka, H. Regulating the ratio of photoautotrophic to heterotrophic metabolic activities in photoheterotrophic culture of Euglena gracilis and its application to $\alpha$-tocopherol production. Biotechnol. Lett. 2002, 24, 953-958. [CrossRef]

5. Wang, Y.; Seppänen-Laakso, T.; Rischer, H.; Wiebe, M.G. Euglena gracilis growth and cell composition under different temperature, light and trophic conditions. PLOS ONE 2018, 13, e0195329. [CrossRef]

6. Hasan, M.T.; Sun, A.; Khatiwada, B.; McQuade, L.; Mirzaei, M.; Te'o, J.; Hobba, G.; Sunna, A.; Nevalainen, H. Comparative proteomics investigation of central carbon metabolism in Euglena gracilis grown under predominantly phototrophic, mixotrophic and heterotrophic cultivations. Algal. Res. 2019, 43, 101638. [CrossRef]

7. Takeyama, H.; Kanamaru, A.; Yoshino, Y.; Kakuta, H.; Kawamura, Y.; Matsunaga, T. Production of antioxidant vitamins, $\beta$-carotene, vitamin C, and vitamin E, by two-step culture of Euglena gracilis Z. Biotechnol. Bioeng. 1997, 53, 185-190. [CrossRef]

8. Barsanti, L.; Bastianini, A.; Passarelli, V.; Tredici, M.R.; Gualtieri, P. Fatty acid content in wild type and WZSL mutant of Euglena gracilis. J. Appl. Phycol. 2000, 12, 515-520. [CrossRef]

9. Kim, S.; Lee, D.; Lim, D.; Lim, S.; Park, S.; Kang, C.; Yu, J.; Lee, T. Paramylon production from heterotrophic cultivation of Euglena gracilis in two different industrial byproducts: Corn steep liquor and brewer's spent grain. Algal. Res. 2020, 47, 101826. [CrossRef]

10. Russo, R.; Barsanti, L.; Evangelista, V.; Frassanito, A.M.; Longo, V.; Pucci, L.; Penno, G.; Gualtieri, P. Euglena gracilis paramylon activates human lymphocytes by upregulating pro-inflammatory factors. Food Sci. Nutr. 2016, 5, 205-214. [CrossRef]

11. Barsanti, L.; Gualtieri, P. Paramylon, a potent immunomodulator from WZSL mutant of Euglena gracilis. Molecules 2019, 24, 3114. [CrossRef] [PubMed] 
12. Koizumi, N.; Sakagami, H.; Utsumi, A.; Fujinaga, S.; Takeda, M.; Asano, K.; Sugawara, I.; Ichikawa, S.; Kondo, H.; Mori, S.; et al. Anti-HIV (human immunodeficiency virus) activity of sulfated paramylon. Antiviral Res. 1993, 21, 1-14. [CrossRef]

13. Aoe, S.; Yamanaka, C.; Koketsu, K.; Nishioka, M.; Onaka, N.; Nishida, N.; Takahashi, M. Effects of paramylon extracted from Euglena gracilis EOD-1 on parameters related to metabolic syndrome in diet-induced obese mice. Nutrients 2019, $11,1674$. [CrossRef] [PubMed]

14. Watanabe, T.; Shimada, R.; Matsuyama, A.; Yuasa, M.; Sawamura, H.; Yoshida, E.; Suzuki, K. Antitumor activity of the $\beta$-glucan paramylon from Euglena against preneoplastic colonic aberrant crypt foci in mice. Food Funct. 2013, 4, 1685-1690. [CrossRef]

15. Nakashima, A.; Suzuki, K.; Asayama, Y.; Konno, M.; Saito, K.; Yamazaki, N.; Takimoto, H. Oral administration of Euglena gracilis $\mathrm{Z}$ and its carbohydrate storage substance provides survival protection against influenza virus infection in mice. Biochem. Biophys. Res. Commun. 2017, 494, 379-383. [CrossRef]

16. Villa, J.A.; Ray, E.E.; Barney, B.M. Azotobacter vinelandii siderophore can provide nitrogen to support the culture of the green algae Neochloris oleoabundans and Scenedesmus sp. BA032. FEMS Microbiol. Lett. 2014, 351, 70-77. [CrossRef]

17. Croft, M.T.; Lawrence, A.D.; Raux-Deery, E.; Warren, M.J.; Smith, A.G. Algae acquire vitamin $B_{12}$ through a symbiotic relationship with bacteria. Nature 2005, 438, 90-93. [CrossRef]

18. Amin, S.A.; Hmelo, L.R.; Tol, H.M.; Durham, B.P.; Carlson, L.T.; Heal, K.R.; Morales, R.L.; Berthiaume, C.T.; Parker, M.S.; Djunaedi, B.; et al. Interaction and signalling between a cosmopolitan phytoplankton and associated bacteria. Nature 2015, 522, 98-101. [CrossRef]

19. Dao, G.; Wang, S.; Wang, X.; Chen, Z.; Wu, Y.; Wu, G.; Lu, Y.; Liu, S.; Hu, H. Enhanced Scenedesmus sp. growth in response to gibberellin secretion by symbiotic bacteria. Sci. Total Environ. 2020, 740, 140099. [CrossRef]

20. Amin, S.A.; Green, D.H.; Hart, M.C.; Küpper, F.C.; Sunda, W.G.; Carrano, C.J. Photolysis of iron-siderophore chelates promotes bacterial-algal mutualism. Proc. Natl. Acad. Sci. USA 2009, 106, 17071-17076. [CrossRef]

21. Amavizca, E.; Bashan, Y.; Ryu, C.-M.; Farag, M.A.; Bebout, B.M.; de-Bashan, L.E. Enhanced performance of the microalga Chlorella sorokiniana remotely induced by the plant growth-promoting bacteria Azospirillum brasilense and Bacillus pumilus. Sci. Rep. 2017, 7, 41310. [CrossRef]

22. Kim, B.H.; Ramanan, R.; Cho, D.H.; Oh, H.M.; Kim, H.S. Role of Rhizobium, a plant growth promoting bacterium, in enhancing algal biomass through mutualistic interaction. Biomass. Bioenergy 2014, 69, 95-105. [CrossRef]

23. Rivas, M.O.; Vargas, P.; Riquelme, C.E. Interactions of Botryococcus braunii cultures with bacterial biofilms. Microb. Ecol. 2010, 60, 628-635. [CrossRef]

24. Tanabe, Y.; Okazaki, Y.; Yoshida, M.; Matsuura, H.; Kai, A.; Shiratori, T.; Ishida, K.; Nakano, S.; Watanabe, M.M. A novel alphaproteobacterial ectosymbiont promotes the growth of the hydrocarbon-rich green alga Botryococcus braunii. Sci. Rep. 2015, 5, 10467. [CrossRef]

25. Park, J.; Park, B.S.; Wang, P.; Patidar, S.K.; Kim, J.H.; Kim, S.H.; Han, M.S. Phycospheric native bacteria Pelagibaca bermudensis and Stappia sp. ameliorate biomass productivity of Tetraselmis striata (KCTC1432BP) in co-cultivation system through mutualistic interaction. Front. Plant Sci. 2017, 8, 289. [CrossRef]

26. Dao, G.H.; Wu, G.X.; Wang, X.X.; Zhang, T.Y.; Zhan, X.M.; Hu, H.Y. Enhanced microalgae growth through stimulated secretion of indole acetic acid by symbiotic bacteria. Algal. Res. 2018, 33, 345-351. [CrossRef]

27. Toyama, T.; Hanaoka, T.; Yamada, K.; Suzuki, K.; Tanaka, Y.; Morikawa, M.; Mori, K. Enhanced production of biomass and lipids by Euglena gracilis via co-culturing with a microalga growth-promoting bacterium, Emticicia sp. EG3. Biotechnol. Biofuels 2019, 12, 205. [CrossRef]

28. Kim, J.Y.; Oh, J.J.; Jeon, M.S.; Kim, G.H.; Choi, Y.E. Improvement of Euglena gracilis paramylon production through a cocultivation strategy with the indole-3-acetic acid-producing bacterium Vibrio natriegens. Appl. Environ. Microbiol. 2019, 85, e01548-19. [CrossRef]

29. Jeon, M.S.; Oh, J.J.; Kim, J.Y.; Han, S.I.; Sim, S.J.; Choi, Y.E. Enhancement of growth and paramylon production of Euglena gracilis by co-cultivation with Pseudoalteromonas sp. MEBiC 03485. Bioresour. Technol. 2019, 288, 121513. [CrossRef]

30. Jeon, M.S.; Han, S.I.; Kim, J.Y.; Choi, Y.E. Co-cultivation of Euglena gracilis and Pseudoalteromonas sp. MEBiC 03607 for paramylon production. J. Appl. Phycol. 2020, 32, 3679-3686. [CrossRef]

31. Toyama, T.; Kasuya, M.; Hanaoka, T.; Kobayashi, N.; Tanaka, Y.; Inoue, D.; Sei, K.; Morikawa, M.; Mori, K. Growth promotion of three microalgae, Chlamydomonas reinhardtii, Chlorella vulgaris and Euglena gracilis, by in situ indigenous bacteria in wastewater effluent. Biotechnol. Biofuels 2018, 11, 176. [CrossRef]

32. Rahman, A.; Sitepu, I.R.; Tang, S.Y.; Hashidoko, Y. Salkowski's reagent test as a primary screening index for functionalities of rhizobacteria isolated from wild dipterocarp saplings growing naturally on medium-strongly acidic tropical peat soil. Biosci. Biotechnol. Biochem. 2010, 74, 2202-2208. [CrossRef]

33. DuBois, M.; Gilles, K.A.; Hamilton, J.K.; Rebers, P.A.; Smith, F. Colorimetric method for determination of sugars and related substances. Anal. Chem. 1956, 28, 350-356. [CrossRef]

34. Hipkins, M.F.; Baker, N.F. Photosynthesis: Energy Transduction a Practical Approach; IRL Press: Oxford, UK, 1986.

35. Davin-Regli, A.; Lavigne, J.-P.; Pagès, J.M. Enterobacter spp.: Update on taxonomy, clinical aspects, and emerging antimicrobial resistance. Clin. Microbiol. Rev. 2019, 32, e00002-19. [CrossRef] [PubMed] 
36. Mazalan, N.Z.S.; Oyeleye, A.; Rahman, R.N.Z.R.A.; Aris, A.Z.; Salleh, A.B.; Normi, Y.M. Isolation and characterization of an acid and metal tolerant Enterobacter cloacae NZS strain from former mining lake in Selangor, Malaysia. Beni-Suef Univ. J. Basic Appl. Sci. 2020, 9, 27. [CrossRef]

37. Sanket, A.S.; Ghosh, S.; Sahoo, R.; Nayak, S.; Das, A.P. Molecular identification of acidophilic manganese (Mn)-solubilizing bacteria from mining effluents and their application in mineral beneficiation. Geomicrobiol. J. 2017, 34, 71-80. [CrossRef]

38. Kim, S.H.; Kim, I.H.; Lee, W.J.; Lee, J.H. Characterization of thiosulfate-oxidizing Enterobacter hormaechei JH isolated from barnyard manure. Korean J. Chem. Eng. 2008, 25, 1131-1135. [CrossRef]

39. Joung, Y.; Seo, M.A.; Kang, H.; Kim, H.; Ahn, T.S.; Cho, J.C.; Joh, K. Emticicia aquatica sp. nov., a species of the family Cytophagaceae isolated from fresh water. Int. J. Syst. Evol. Microbiol. 2015, 65, 4358-4362. [CrossRef]

40. Nam, G.G.; Joung, Y.; Song, J.; Lim, Y.; Cho, J.C. Emticiciafontis sp. nov., isolated from a freshwater pond. Int. J. Syst. Evol. Microbiol. 2016, 66, 5161-5166. [CrossRef]

41. Ten, L.N.; Li, W.; Ha, A.; Kim, M.K.; Rooney, A.P.; Jung, H.Y. Emticicia agri sp. nov., a novel member of the family Cytophagaceae. Int. J. Syst. Evol. Microbiol. 2019, 69, 3492-3499. [CrossRef]

42. Masojídek, J.; Torzillo, G.; Koblížek, M. Photosynthesis in microalgae. In Handbook of Microalgal Culture: Applied Phycology and Biotechnology, 2nd ed.; John Wiley \& Sons: West Sussex, UK, 2013; pp. 21-36.

43. Zhu, J.; Wakisaka, M. Growth promotion of Euglena gracilis by ferulic acid from rice bran. AMB Express 2018, 8, 16. [CrossRef] [PubMed]

44. Noble, A.; Kisiala, A.; Galer, A.; Clysdale, D.; Emery, R.J.N. Euglena gracilis (Euglenophyceae) produces abscisic acid and cytokinins and responds to their exogenous application singly and in combination with other growth regulators. Eur. J. Phycol. 2014, 49, 244-254. [CrossRef] 